\title{
Третинний перитоніт як проблема абдомінальної хірургіi
}

\author{
П. Д. Фомін ${ }^{1}$, О. Б. Матвійчук ${ }^{2}$ \\ ${ }^{1}$ Національний медичний університет імені О. О. Богомольця МОЗ України, м. Київ, \\ ${ }^{2}$ Львівський Національний медичний університет імені Данила Галицького

\section{Tertiary peritonitis as a problem of abdominal surgery}

\author{
P. D. Fomin ${ }^{1}$, O. B. Matviychuk ${ }^{2}$
}

${ }^{1}$ Bogomolets National Medical University, Kyiv,

${ }^{2}$ Danylo Galytskyi Lviv National Medical University

\section{Реферат}

Вступ. Результати лікування абдомінального сепсису (AC) незадовільні. Найтяжчою його формою є третинний перитоніт (ТП). Факторами, що обтяжують перебіг ТП, є прогресування антибіотикорезистентності, зменшення резервів антибактеріальної терапії, поліморбідність. Сьогодні немає дієвих шкал прогнозування перебігу ТП, що робить проблему однією з найгостріших в абдомінальній хірургії.

Мета. Опрацювати спосіб прогнозування перебігу ТП для покращання його діагностики й лікування.

Матеріали і методи. Проспективно обстежені 109 пацієнтів 3 приводу перитоніту. У 18,3\% хворих на 3 - 12-ту добу виявлені ознаки ТП, від якого померли 90\% хворих.

Результати. 3 використанням статистичного методу відібрані 19 найбільш прогностично значущих показників, інтегровані у шкалу прогнозування ризику виникнення ТП, що відзначалася високим ступенем точності, специфічності та чутливості.

Висновки.

1. ТП є найтяжчою формою АС.

2. Застосування запропонованої шкали дозволило з високою точністю прогнозувати ризик виникнення ТП.

3. Застосування шкали прогнозування ризику виникнення ТП сприяло ефективній діагностиці захворювання.

ключові слова: абдомінальний сепсис; третинний перитоніт; прогнозування ризику виникнення. Abstract

Introduction. Results of treatment of abdominal sepsis are poor. Tertiary peritonitis (YP) constitutes a most severe its form. The antibioticoresistance progress, the reduction of the antibacterial therapy reserves, as well as polymorbidity, constitute the factors, which complicate the TP course. Nowadays there are no efficient scales for the course prognosis in TP, making the problem one of the most acute in abdominal surgery.

Objective. To elaborate the method of prognosis of the TP course for improvement of its diagnosis and treatment.

Materials and methods. For the peritonitis diagnosis 109 patients were prospectively examined. In $18,3 \%$ of the patients on $3-12$-th day the TP signs were revealed, due to which $90 \%$ of the patients died.

Results. Using statistical method, 19 most prognostically significant indices were choose, integrated into the prognostic scale of the TP occurrence, demonstrating it is highly precise, specific and sensitive.

Conclusion.

1. Tertiary peritonitis is a most severe form of abdominal sepsis.

2. Application of the scale proposed have permitted to prognosticate the TP occurrence risk with high precision.

3. Application of the prognosis scale for determination of the TP occurrence risk have promoted the disease effective diagnosis. Keywords: abdominal sepsis; tertiary peritonitis; prognosis of the occurrence risk.

Абдомінальний сепсис (АС) протягом тривалого часу є предметом численних наукових досліджень, проте і сьогодні результати його лікування невтішні [1, 2]. Найтяжчим щодо перебігу і прогнозу є ТП [3, 4]. Факторами, що обтяжують перебіг ТП, прогресування антибіотикорезистентності патогенної мікрофлори, особливо нозокоміальної, зниження резервів ефективної антибактеріальної терапії, поліморбідність у зв'язку з глобальним постарінням населення $[5,6]$.

Труднощі діагностики, профілактики й лікування ТП, значною мірою зумовлені відсутністю дієвих інтегральних шкал прогнозування, визначають складність проблеми ТП як однієї з гострих і невирішених у сучасній абдомінальній хірургіi.

Мета дослідження: опрацювати спосіб прогнозування ТП для покращання його діагностики й лікування.

\section{Матеріали і методи дослідження}

Проведене проспективне обстеження 109 пацієнтів, оперованих з приводу перитоніту в клініці хірургії та ендоскопії ЛНМУ імені Данила Галицького за період 2010 - 2015 рр. Причинами виникнення перитоніту були: гострий деструктивний апендицит (у 29,4\% хворих), проривна виразка шлунка (в 11\%) або дванадцятипалої кишки (у 7,3\%), перфораційний рак товстої кишки (в 11\%), перфораційний дивертикуліт товстої кишки (у 6,5\%), абсцес черевної порожнини з проривом (у 5,6\%), гострий деструктивний холецистит 3 перфорацією (у 4,7\%), тромбоемболія верхньої брижової артерії з некрозом тонкої кишки (у 3,6\%), перфорація раку шлунка (у 3,6\%), хвороба Крона з перфорацією тонкої кишки (у 3,6\%), защемлення грижі з некрозом тонкої кишки (у 2,8\%), тяжка політравма з ушкодженням тонкої кишки (у 2,8\%), роз- 
пад та нагноєння пухлини заочеревинного простору $з$ проривом абсцесу в черевну порожнину (у 1,8\%), пухлина матки з проростанням тонкої кишки та іiі некрозом (у 0,9\%), панкреонекроз (у 0,9\%), заворот сигмоподібної ободової кишки з перфорацією (у 0,9\%), виразковий коліт з некрозом ободової кишки (у 0,9\%), перфораційний рак тонкої кишки (у 0,9\%), рак підшлункової залози з розпадом (у 0,9\%), перфорація шлунка стороннім тілом (у 0,9\%). Супутні захворювання діагностовані у 88 (80,7\%) пацієнтів. Жінок було 57 (52,3\%), чоловіків - 52 (47,7\%). Вік пацієнтів від 18 до 88 років (медіана 61 рік). Через тяжкість стану, більшість $(62,4 \%)$ хворих протягом 1 - 4 діб після операції перебували у відділенні анестезіології та інтенсивної терапії (BAIT). Місцевий невідмежований перитоніт відзначений у 104 (95,4\%) хворих, дифузний - у 88 (80,7\%). Післяопераційні ускладнення виникли у 16,5\% хворих, 3 них у 50\% - гнійно-септичні. Ознаки ТП виявлені на 3 - 12-ту добу у 20 (18,3\%) хворих. Діагноз ТП встановлювали за наявності таких ознак: персистенція перитоніту, виявлення нозокоміальної мі-

\begin{tabular}{|c|c|c|}
\hline \multicolumn{3}{|c|}{$\begin{array}{c}\text { Таблиця 1. Оцінювання показників прогнозу ризику } \\
\text { виникнення ТП }\end{array}$} \\
\hline Показник & Значення / ранг & Бал \\
\hline \multirow{2}{*}{ Тривалість операції, хв } & 120 і менше & -1 \\
\hline & Більше 120 & 3 \\
\hline \multirow{2}{*}{ Кількість ексудату, мл } & 1000 і менше & -1 \\
\hline & Більше 1000 & 4 \\
\hline \multirow{2}{*}{ Дифузний перитоніт } & Так & 1 \\
\hline & $\mathrm{Hi}$ & -7 \\
\hline \multirow{2}{*}{$\begin{array}{l}\text { Місцевий } \\
\text { невідмежований } \\
\text { перитоніт }\end{array}$} & Так & 1 \\
\hline & $\mathrm{Hi}$ & -6 \\
\hline \multirow{2}{*}{$\begin{array}{l}\text { Кількість уражених зон } \\
\text { черевної порожнини }\end{array}$} & $1-4$ & -6 \\
\hline & Більше 4 & 7 \\
\hline \multirow{2}{*}{ МІП, ступінь тяжкості } & $I-I I$ & -2 \\
\hline & III & 4,5 \\
\hline \multirow{2}{*}{ APACHE-III, балів } & Менше 100 & -6 \\
\hline & 100 і більше & 2,5 \\
\hline \multirow{2}{*}{ Тривалість ШВЛ, год } & $0-10$ & -7 \\
\hline & Більше 10 & 3 \\
\hline \multirow{2}{*}{ Гемоглобін, г/л } & Менше 100 & 4,5 \\
\hline & 100 і більше & -1 \\
\hline \multirow{2}{*}{ Лімфоцити, \% } & Менше 15 & 2 \\
\hline & 15 і більше & -2 \\
\hline \multirow{2}{*}{ תII } & Менше 7 & -2 \\
\hline & Більше 7 & 2 \\
\hline \multirow{2}{*}{ Ф। } & Менше 95 & 2,5 \\
\hline & 95 і більше & $-1,5$ \\
\hline \multirow{2}{*}{$\begin{array}{l}\text { Кортизол у сироватці } \\
\text { крові, нмоль/л }\end{array}$} & 1500 і менше & 2 \\
\hline & Більше1500 & -2 \\
\hline \multirow{2}{*}{$\begin{array}{l}\text { Прокальцитонін у } \\
\text { сироватці крові, нг/мл }\end{array}$} & Менше 12 & $-1,5$ \\
\hline & 12 і більше & 3,5 \\
\hline \multirow{2}{*}{$\begin{array}{l}\text { Загальний білок у } \\
\text { сироватці крові, г/л }\end{array}$} & Менше 70 & 2 \\
\hline & Більше 70 & -6 \\
\hline \multirow{2}{*}{ IgA у сироватці крові, г/л } & 8 і менше & 2 \\
\hline & Більше 8 & -9 \\
\hline \multirow{2}{*}{ IgM у сироватці крові, г/л } & 6 і менше & 2 \\
\hline & Більше 6 & -9 \\
\hline \multirow{2}{*}{$\begin{array}{l}\text { ІЛ-10 у сироватці крові, } \\
\text { пг/мл }\end{array}$} & 17 і менше & 1,5 \\
\hline & Більше 17 & -4 \\
\hline \multirow{2}{*}{$\begin{array}{l}\text { Сечовина у сироватці } \\
\text { крові, ммоль/л }\end{array}$} & 7,5 і менше & $-7,5$ \\
\hline & Більше 7,5 & 1,5 \\
\hline
\end{tabular}

крофлори (Acinetobacter baumannii, Pseudomonas spp., Citrobacter freundii, Staphylococcus viridans, Candida spp., Geotrichum candidum тощо) 3 перитонеального ексудату, поліорганна недостатність (ПОН). Тривалість лікування хворого у ВАIT - 3 доби і більше. Післяопераційна летальність становила 30,2\%, від ТП померли 90\% хворих. Основною причиною смерті був сепсис.

У дослідженні ми керувались консенсусом «Sepsis-3» [7].

Хворі розподілені на 2 групи, у 89 з них діагностований вторинний перитоніт (ВП), у 20 - ТП. Аналізували такі клініко-анамнестичні показники: вік, стать, тривалість лікування у стаціонарі та BAIT, наявність супутніх захворювань, період від початку захворювання до госпіталізації, період від госпіталізації до оперативного втручання, наявність септичного шоку, тривалість операції, поширення перитоніту, кількість контрапертур, об'єм перитонеального ексудату, тривалість штучної вентиляції легень (ШВЛ). Стан хворих за шкалами qSOFA, APACHE-III, POSSUM та Мангеймським індексом перитоніту (МІП) оцінювали в день оперативного втручання, у день встановлення діагнозу ТП та на наступну добу. 3 лабораторних показників серійно (після госпіталізації, на 3-тю та 7-му добу; у групі ТП - додатково в день встановлення діагнозу та на наступну добу) проводили загальний аналіз крові з лейкоцитарною формулою, визначали кількість тромбоцитів, рівень глюкози в крові, обчислювали лейкоцитарний індекс інтоксикації (ЛІІ), фагоцитарний індекс (ФI), фагоцитарне число (ФЧ), у сироватці крові - вміст загального білка, загального фібриногену, лактату, сечовини, креатиніну, інтерлейкінів (ІЛ), ІЛ-1 $\beta$, ІЛ-4, ІЛ-10, фактора некрозу пухлин- $\alpha$, імуноглобулінів (Ig), в тому числі IgA, IgM, IgG, кортизолу, прокальцитоніну, C-реактивного протеїну.

Вміст ІЛ, кортизолу та прокальцитоніну визначали за методом імуноферментного аналізу. Статистична обробка матеріалу проведена з використанням програми Statistica 5.0. Перед вибором методу міжгрупового порівняння параметричних показників або під час повторних досліджень перевіряли нормальність розподілу за критерієм Шапіро-Уїлка.

\section{Результати}

3 використанням методу послідовного аналізу Вальда відібрані 19 предиктивно найбільш цінних показників, інтегрованих у бальну шкалу прогнозу ризику виникнення ТП (табл. 1). Залежно від значення цифрових показників та полярності («так» або «ні») фактичних показників їм присвоювали відповідний бал зі значенням «+» або «-«. Прогнозування відбувалося шляхом підсумовування балів. Сума балів менше 0 відповідала низькому, менше 10 - дуже низькому ризику виникнення ТП; 0 - 10 балів - високому, більше 10 балів - дуже високому ризику виникнення ТП.

\begin{tabular}{|c|c|c|c|c|}
\hline \multicolumn{5}{|c|}{$\begin{array}{c}\text { Таблиця 2. Розподіл хворих за результатами } \\
\text { прогнозування }\end{array}$} \\
\hline Сума балів & ТП & $\%$ & ВП & $\%$ \\
\hline Менше -10 & - & - & 75 & 91,46 \\
\hline Від -10 до 0 & - & - & 1 & 1,22 \\
\hline Від 0 до 10 & - & - & 4 & 4,88 \\
\hline Більше 10 & 2 & 100 & 2 & 2,44 \\
\hline
\end{tabular}


Під час клінічної апробації шкали в незалежній неперервній проспективній групі з 84 хворих відзначено чутливість - 100\% (95\% DI 15,8-100), специфічність 91,4\% (95\% DI 83,2-96,5), загальну точність - 91,7\% (табл. 2).

\section{Обговорення}

Отримані нами результати зіставні з такими інших дослідників. Так, появу дифузного перитоніту та значної кількості перитонеального ексудату вважають однією з умов подальшої персистенції перитоніту [8]. Поряд 3 кількістю уражених анатомічних зон очеревини, ці характеристики набувають прогностичної сили при ТП. Тривалість оперативного втручання та ШВЛ безпосередньо пов'язана зі стресом та ризиком появи високорезистентних штамів нозокоміальної інфекції [9]. Суттєвий негативний вплив на прогноз сепсису мають зміни ЛІІ, відносна лімфоцитопенія, збільшення вмісту сечовини у сироватці крові [10]. Такі самі закономірності відзначені і в нашому дослідженні ризику виникнення ТП. Каскадні зміни різних ІЛ як в бік збільшення, так і зменшення, виснажують ресурс імунітету [11]. Найбільш прогностично чутливим щодо виникнення ТП виявився ІЛ-10. У пацієнтів при ТП виявлені істотно більші показники APACHE-II і МIП, ніж при ВП [6]. За результатами дослідження, шкала APACHE-III та МІП мають індикативність щодо виникнення ТП вже в день госпіталізації хворого. Зниження рівня загального білка, IgA, IgM, IgG супроводжує ВП [12]. При прогнозуванні виникнення ТП статистично значущими були зміни рівня IgA та загального білка. Збільшення концентрації прокальцитоніну вважають ознакою прогресування сепсису [13]. У нашому дослідженні вміст прокальцитоніну виявився високопрогностично чутливим як один $з$ основних біомаркерів сепсису та ТП. Відзначена відповідність рівня кортизолу в сироватці крові вираженості стресової реакції хворого, що свідчило про важливість недостатності надниркових залоз як компонента ПОН у хворих при ТП [14]. Підтвердження цьому отримали і ми у дослідженні.

Багатоплановість змін гомеостазу хворого при сепсисі спонукала клініцистів розробляти бальні шкали оцінювання тяжкості стану, прогнозу виникнення післяопераційних ускладнень чи ймовірності летального кінця: МIП, SOFA, SAPS, P-POSSUM, PIA, MODS тощо [15]. Проте для прогнозування виникнення ТП вони малопридатні, оскільки не мають специфічності до нього. Запропонована нами шкала прогнозування дозволяє стратифікувати хворих за ризиком виникнення ТП, вчасно встановлювати показання до застосування діагностично-лікувальної тактики, використовуючи бальне оцінювання періопераційних лабораторних і фактичних показників.

\section{Висновки}

1. ТП є прогностично найтяжчою формою АС, що характеризується складною діагностикою і незадовільними результатами лікування.

2. Застосування запропонованої шкали дозволило 3 високою точністю прогнозувати ризик виникнення ТП.

3. Використання шкали прогнозування виникнення ТП сприяло його ефективній діагностиці, лікуванню й профілактиці.

\section{References}

1. Kryvoruchko IA, Boyko VV, Syvozhelezov AV. Rozpovsiudzhenyi hniinyi perytonit. Halytskyi likarskyi visnyk. 2012;19(3):71-3. [In Ukrainian].

2. De Sol A, Bisagni P, Ribaldi S, Bertolucci A, Chirocchi R, Chiarugi M, et al. Septic complications after emergency surgical procedures consensus of Italian society on trauma and emergency surgery. Rev Med Chir Soc Med Nat Iaşi. 2017;121(1):136-42.

3. Riché F, Gayat E, Collet C, Matéo J, Laisné MJ, Launay JM, et al. Local and systemic innate immune response to secondary human peritonitis. Crit Care. 2013 Sep 12;17(5):R201. doi: 10.1186/cc12895.

4. Malangoni MA. Evaluation and management of tertiary peritonitis. Am Surg. 2000;66(2):157-61. PMID: 10695746.

5. Zubkov MN. Algoritmy antibiotikoterapii tjazhelyh bakterialnyh infekcij. Ostrye i neotlozhnye sostojanija v praktike vracha. 2009;3:2-7. [In Russian].

6. Efimova IS. Sistemnaja vospalitelnaja reakcija u bolnyh s vtorichnym i tretichnym peritonitom. Hirurgicheskie infekcii. 2007;1:27-31. [In Russian].

7. Singer M, Deutschman CS, Seymour CW, Shankar-Hari M, Annane D, Bauer M, et al. The Third International Consensus Definitions for Sepsis and Septic Shock (Sepsis-3). JAMA. 2016;315(8):801-10. doi: 10.1001/jama.2016.0287.

8. Koperna T, Schulz F. Relaparotomy in peritonitis: prognosis and treatment of patients with persisting intraabdominal infection. World Jour Surg. 2000;24(1): 32-7. PMID: 10594200.

9. Martínez-Casas I, Sancho JJ, Nve E, Pons MJ, Membrilla E, Grande L. Preoperative risk factors for mortality after relaparotomy: analysis of 254 patients. Langenbecks Arch Surg. 2010;395(5):527-34. doi: 10.1007/s00423-009-0538-0. Epub 2009 Jul 18.

10. Siplivyj VA, Grinchenko SV, Beresnev AV, Evtushenko DV. Khirurgicheskiy sepsis: sovremennye podhody k ocenke tjazhesti. Ukrainskiy zhurnal khirurhiï. 2009;1:121-4. [In Russian].

11. Deikalo IM, Makhnitskyi AV, Sokolyk MB. Imunokorektsiia v kompleksnomu likuvanni khvorykh na hostryi abdominalnyi sepsys. Shpytalna khirurhiia. 2010;(4):27-30. [In Ukrainian].

12. Vasyliuk MD, Kavyn VO. Endotoksykoz u khvorykh z perytonitom i prohnozuvannia yoho perebihu. Halytskyi likarskyi visnyk. 2004;11(4):104-7. [In Ukrainian].

13. Rau BM, Frigerio I, Büchler MW, Wegscheider K, Bassi C, Puolakkainen PA, et al. Evaluation of procalcitonin for predicting septic multiorgan failure and overall prognosis in secondary peritonitis: a prospective, international multicenter study. Arch Surg. 2007;142(2):134-42. doi: 10.1001/archsurg.142.2.134.

14. Marik PE, Zaloga GP. Adrenal insufficiency in the critically ill. Chest. 2002;122: 1784-96. PMID: 1242628.

15. Kamble RS, Singh M, Jaiswal Y. Prognostic factors in perforative peritonitis: an observational study. Int Surg J. 2016;3(3):1082-92. 